\title{
Sobre ancestralidade, minha vó Eliza e o Teatro Russo
}

\section{On ancestry, my grandmother Eliza and the Russian Theatre}

\begin{abstract}
Thábata Marques Liparotti
Doutoranda no Programa de Pós-graduação em Artes Cênicas da Escola de Comunicações e Artes da Universidade de São Paulo (PPGAC-ECA-USP) pelo DINTER ECA-USP/UFS e docente do departamento de Dança da Universidade Federal de Sergipe (UFS). Pesquisadora-artista-educadora, montanhista-dançarina, mãe, filha, (e aqui, sobretudo) neta, artífice, costureira e bordadeira, graduada em dança, mestre em comunicação e semiótica, doutoranda em artes cênicas e professora.
\end{abstract}

thalipa@gmail.com - https://orcid.org/0000-0003-3310-5872

\section{Resumo}

Este painel é fruto da busca de um modo de escrever para uma pesquisa em artes. Ao entrelaçarem-se as memórias de infância e as ancestrais, a costura e o bordado emergiram como estratégia qualitativa para lidar com o pensamento do corpo. Compreende-se, assim, que as memórias e a ancestralidade ucraniana organizam o modo como este corpo cria e constrói suas conexões. Ao retomar fazeres apreendidos na infância, a tecitura se torna o fio que adentra o tecido e amarra os elos da construção acadêmica, artística e pedagógica, aqui indissociáveis. Três dimensões do coser e do bordar podem ser apontadas: as costuras metafóricas que amarraram ideias em texto, a tessitura metafórica de movimentos em dança e a costura concreta do texto-tecido que organiza a amarração e união dos textos entre eles. Todas bordam significados sobrepostos e produzem resultados estéticos.

Palavras-chave: Ancestralidade. Teatro Russo. Pesquisa em dança.

\section{Abstract}

This panel is the result of a pursuit of a writing style to a research on Art. Entwining childhood and Ukrainian ancestral memories, the seam and the embroidery emerged as a qualitative strategy to deal with the body's thinking. Such memories organized thus the way this body creates and builds its connections. Since the weave resumes doings apprehended in childhood, the thread enters the textile and ties the links among academic, artistic and pedagogical creation which here are such an amalgam. Consequentily, three dimensions of sewing and embroidering may be pointed out: the metaphorical seams which tied ideas into a text, the metaphorical weaving of dance movements and the concrete seam of the text-tissue which binds the texts among them. All seams, therefore, embroider overlapping meanings and produce aesthetic results.

Keywords: Ancestry. Russian Theatre. Research on dance. 


\section{Apresentação}

Este texto-tecido, que se organiza como um painel, surgiu da demanda da disciplina Da pedagogia à cena (C. Stanislavski - J. Grotowski), da cena à pedagogia (V. Meierhold - T. Kantor): perspectivas, heranças e fricções ${ }^{1}$ de se encontrar uma escrita que corroborasse a relação amalgamada entre forma e conteúdo intrínseca às pesquisas em artes.

Esse pedido gerou uma inquietação que foi fomentada pelo estudo do teatro russo, na disciplina de Maria Thaís, em que se priorizaram as figuras dos encenadores Stanislawiski e Meierhold, que se mostram, em seus fazeres artísticos, também pedagogos. A reflexão sobre a não separação entre teoria e prática no fazer artístico-pedagógico, proposta por Thaís (2009), fez-me surgir a ideia do tecido.

Afora isso, a partir da reflexão sobre tal amálgama, começou-se a indagar se os meus modos de pensar arte não possam provir da minha ancestralidade eslava. $O$ termo ancestralidade latu sensu significa qualidade de ancestral, legado de antepassados, ancestral relativo ou próprio dos antepassados ou antecessores, que vem dos avós ou dos antepassados, ou seja, avito. Stricto sensu, todavia, o termo é recorrentemente associado a estudos feministas sobre uma ancestralidade afrobrasileira $^{2}$, que buscam saciar a urgente necessidade de reconstituir essa faceta da história, tão calada, ocultada e massacrada pelo preconceito e racismo em nosso país.

Pede-se licença para também neste estudo fazer uso desse termo que, embora não tenha sido teoricamente conceituado ou definido, parece se ajustar bem a uma das questões investigadas por este trabalho, quer seja, a minha ancestralidade eslava, herdada por meio de minha avó que era neta de ucranianos vindos para o Brasil no período pós-guerra. Ancestralidade essa que foi tão presente em minha história, dado que, quer pela culinária, quer pela manutenção de ritos e fazeres diários, minha avó esforçou-se por manter viva essa tradição. Torna-se frutífera a referência aos contos de Machado (2007), intitulados Bisa Bia, Bisa Bel, cuja história diz respeito a uma menina que descobre suas origens através da foto de sua bisavó,

\footnotetext{
${ }^{1}$ Doutorado do Programa de Pós-graduação em Artes Cênicas da Escola de Comunicações e Artes da Universidade de São Paulo.

${ }^{2}$ Cf. Falcão (2006), Oliveira (2017) e Sodré (2017).
} 
evidenciando a importância de reconhecer lugares de origem, entrelaçamentos culturais e a formação de nossa história pessoal e coletiva.

Recorta-se, portanto, aqui, ancestralidade a partir da minha relação com os meus antepassados por meio dos fazeres aprendidos - dentre eles a costura, o bordado, o plantio - e das tradições culturais, como a culinária e as celebrações com seus rituais. É válido sublinhar que minha vó Eliza, herdeira de tal tradição, sempre ensinou por uma pedagogia do aprender fazendo que não tinha passo a passo ou explicações teóricas, mas simplesmente fazia-se. E quer pela observação, quer pela repetição do fazer, apreendia-se. Eliza Semes ${ }^{3}$, portanto, se torna aqui uma referência de pesquisa, por ter-me ensinado a costura, o bordado e o plantio, fazeres que organizaram e organizam o pensamento deste corpo.

O texto-tecido então é composto de vários textos-retalhos. Cada um deles foi escrito para que coubesse nos cortes de tecido e neles impresso, como uma estampa. A partir daí, dá-se a tecitura, buscando suas conexões, sua coesão, sua coerência.

No fazer, no compor e no montar é que se compreende quem se alinhavava com quem. Depois, costurar-se aos pares e então as tiras de três, até formar um painel retangular. Nove partes. Três por três.

A decisão inicial deu-se pelo centro. O trecho Elos que se atam precisava estar no centro e ser costurado com todos os demais, pois ele amarra a significação dos demais e tece a organização central do painel. Nas quinas no pano, estão os outros quatro textos. Na quina superior esquerda um pouco da história familiar; na superior direita um relato do fazer artístico e o eixo de pesquisa em artes; na inferior esquerda uma descrição dos fazeres da terra, entre plantar e colher, que permeia a relação corpo e ambiente nesse fazer; e por fim, na inferior direita, uma reflexão sobre a escrita em artes e os modos, escolhas e novos olhares deste fazer.

Pode-se iniciar a leitura por qualquer parte, não há ordem, mas sim uma organização estética composta pelos quatro entremeios que não são meramente ilustrativos, mas possuem histórias visuais ${ }^{4}$, manuais e fazem parte de uma cultura

\footnotetext{
${ }^{3}$ Sua história será abordada brevemente no texto tecido, no retalho intitulado "Histórias de família...".

${ }^{4} \mathrm{O}$ entremeio inferior é composto por cinco fotografias do acervo pessoal: Figura 1 (superior esquerda) Família em frente à Igreja Ucraniana em Curitiba-PR; Figura 2 (superior direita) Mãe Pepita Liparotti e filha Thabata Liparotti com 2 anos numa sexta-feira santa no benzimento da cesta de Páscoa no bosque do Papa e Memorial da imigração Polonesa em Curitiba - PR Foto 3 (central) Avó Eliza e netos Thábata (9) e Renan (6) numa sexta-feira santa no quintal de casa rumo ao benzimento
} 
oral. O bordado, tão marcante e presente em minha vida e na história dos meus antepassados, vem para o texto e finaliza, sobrepondo fios e significados.

Desse processo surgiu um novo desafio, o de trazer para os moldes digitais o painel como um modo de escrita de pesquisa em artes. Como o texto-tecido tão palpável, manual, pode adentrar as bibliotecas e revistas do meio acadêmico?

Assim, o registro fotográfico emerge como solução. Surge da demanda de não se perder as características do tecido que dão forma e significado a este texto-tecido. As imagens precisavam ser legíveis, mas, ao mesmo passo, não deveriam se tornar tão planas quanto um papel ou uma tela.

A maleabilidade do tecido, os retângulos não tão retangulares, o pano que voa, que se amassa e que toma forma do ambiente, sua permeabilidade à luz e transparência precisavam ser evidenciados. Elementos que se tornaram parte do processo de registro.

No formato digital, todavia, a sequência linear das imagens não compõe um painel. Por isso, a primeira página do texto é uma imagem do todo, sua apresentação. Partindo dessa observação primeira, a leitora ou o leitor pode percorrer o texto como Ihe for mais interessante, compreendendo o todo sem buscar uma organização através do sequenciamento de páginas, mas por meio das costuras.

Sendo assim, essa leitura indicada é apenas uma proposição. Mesmo que de natureza visual, espera-se que as imagens possam trazer um pouco do tato, das texturas, das ranhuras, das imperfeições e da beleza de um trabalho manual.

Thábata Marques Liparotti Maio 2020

da cesta de Páscoa. Figura 4 (inferior esquerda) Mesmo local e data da foto 2, agora pai João Roberto e filha Thábata. Figura 5 (inferior direita) Mesmo local e data da foto 3 irmãos Thábata e Renan e cesta de Páscoa em destaque. 


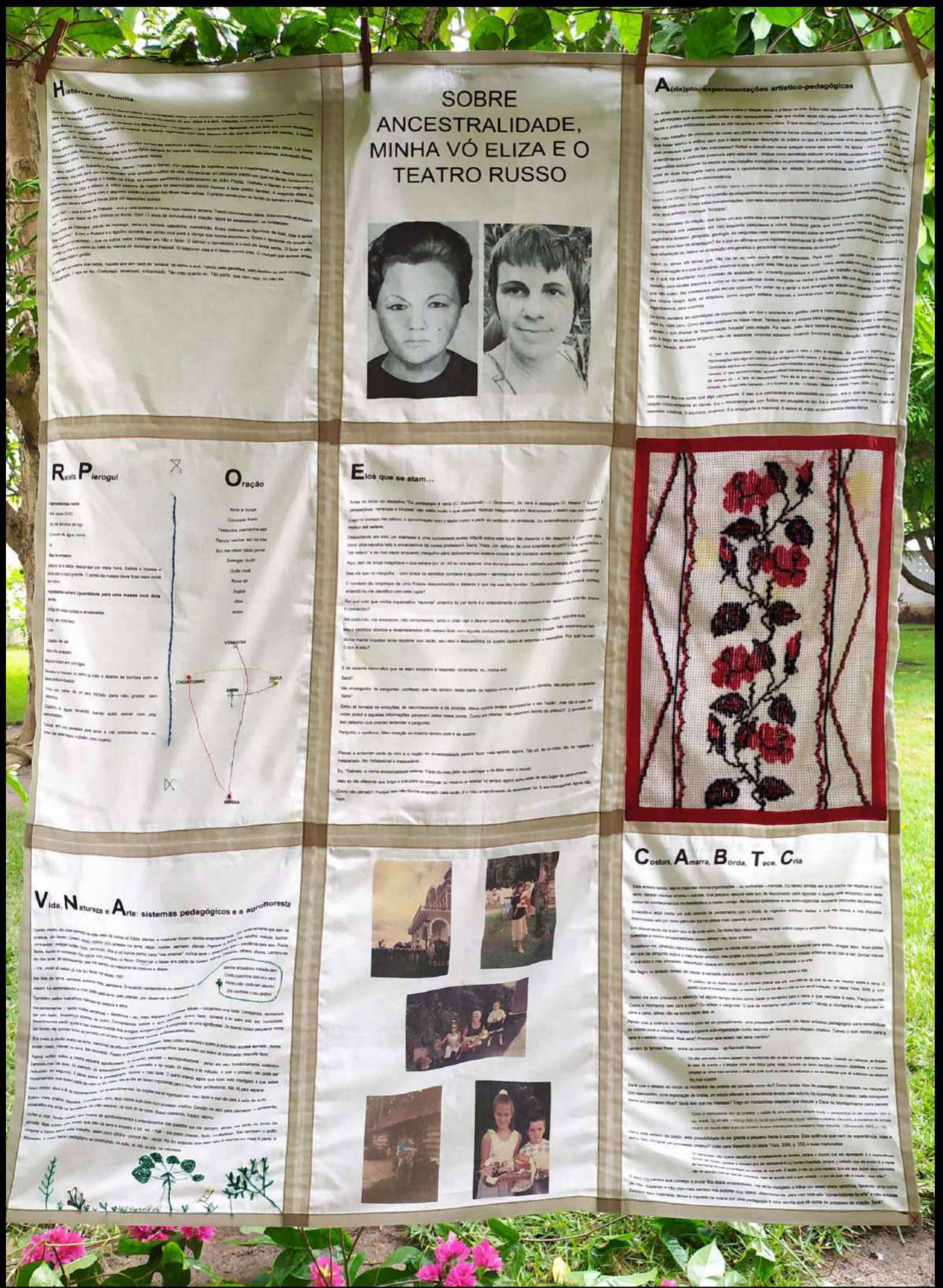




\section{C. $\mid D^{2}$}

\section{SOBRE}

ANCESTRALIDADE,

MINHA VÓ ELIZA E O

TEATRO RUSSO
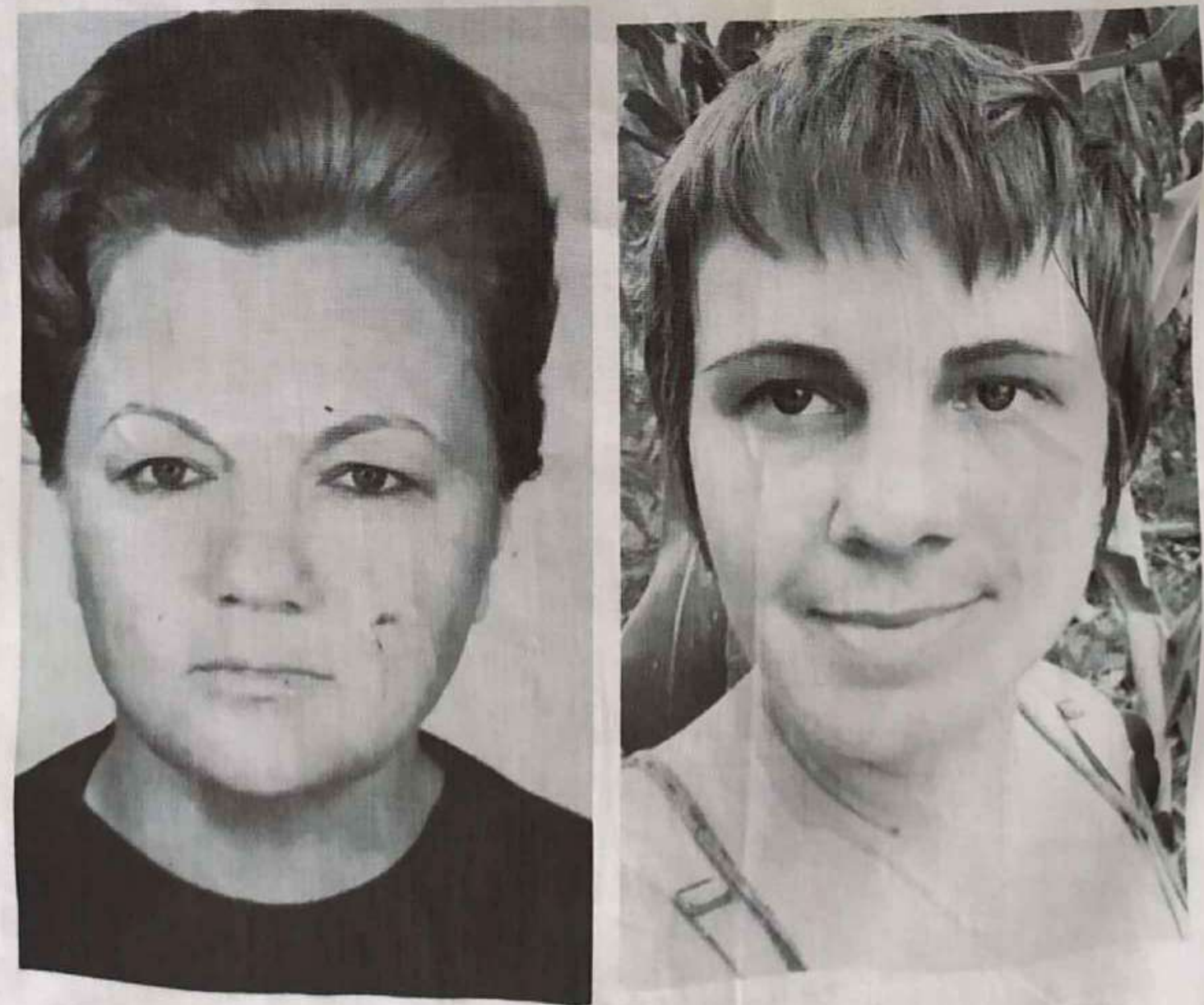

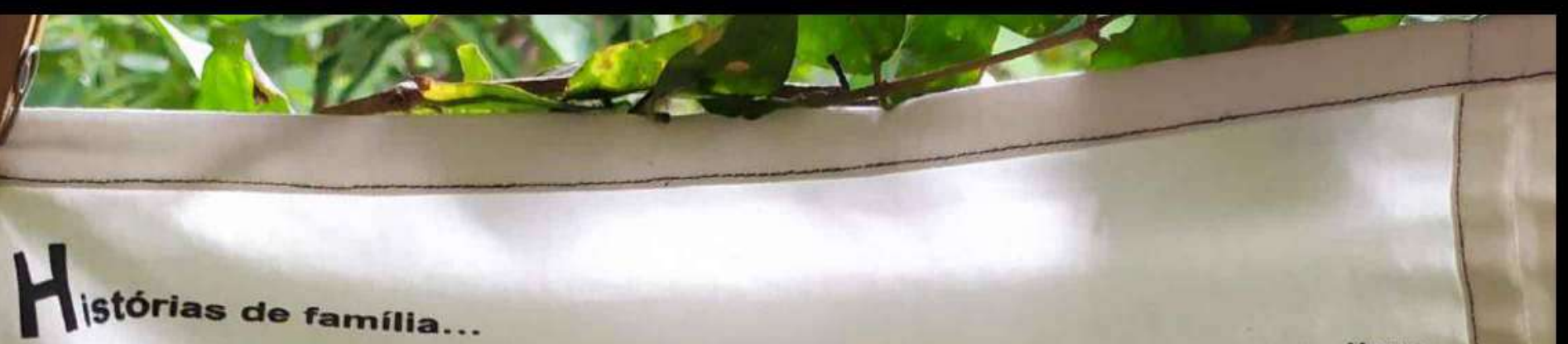

\section{de ramilia...}

Numa familia em que a matriarca é descendente de ucranianos nasce uma menina. Neta mulher mais nova dentre nosa. cara de "bolacha", mesmos olhos azuis e cabelos claros herdados da avo. Eliza é a avo, Thabata, a menina, sempcol, de um jeito que nunca soubemos Eliza Saico como era conhecida, na verdade era Eliza Semes - no registro - que deveria ser sempcol, de que se conta que ela nasceu. A familia escrever, nem tampouco ela. Nascida no interior do Paraná, registrada com data dispare do dia que se conta que ela nasceu. Alaa era da roça, da regiấo da Lapa.

Eliza estudou pouco, quando moça já em Curitiba tomou-se manicure e cabeleireira. Casou-se com Wilson e teve três filhos: Lia Mara, Elizabeth $e$ Joâo Roberto. Mulher alta, sua força fisica sempre foi marcante. Inquieta, trabalhadora, amante das plantas, sobretudo flores. Conhecida como "dedo verde" pois tudo que plantava nascia.

De seu caçula, Joåo Roberto e Pepita, nasceu Thábata e Renan. Por questōes de logistica, saúde e investimento Joăo decide construir no terreno dos pais para dar-lhes também uma condiçăo melhor de vida. Construi-se um pequeno prédio em que no térreo funcionava a academia de balé de Pepita e o salăo de Eliza, no primeiro pavimento o apartamento de Joăo, Pepita, Thábata e Renan e no segundo o apartamento de Eliza e Wilson. A velha casinha de madeira foi desmontada dando espaço a este prédio familiar. A segunda etapa do projeto nunca foi para frente com o segundo prédio que seria das filhas mais velhas. O prédio construido no fundo do terreno e o desmonte da casinha deram espaço a frente para um espaçoso quintal.

Ali em 1991 - aos 4 anos de Thábata - avó e neta passam a morar num mesmo terreno. Tendo convivência diária. Esta jornada se encerra aos 17 anos em Natal no Rio Grande do Norte. Com 13 anos de convivência e criaçăo, laços se estabelecem, se fortalecem.

Entre feitios de Pierogui, plantio de morango, cenoura, hortelā, cebolinha, manjericăo. Entre costuras de figurinos de bale, idas à igreja "dos uncrainos". Entre o Poltava e o figurino bordado em ponto cruz para a dança que nunca aconteceu. Entre o aprender da oraçăo do santo anjo em ucraniano - que os outros netos insistiam em não o fazer. O benzer o carneirinho e o ovo da sexta santa. $O$ fazer o pão. arumar os frios e a mesa do café da manhā do domingo de Páscoa. $\mathrm{O}$ cristovos cres e o naiste novos cres. O roulupti que ambas amam e que todos fingiam gostar.

A neta mais ucraniana dos netos. Aquela que tem cara de "polaca" tal como a avó. Talvez pela genética, pelo destino ou pela proximiade e identificaçăo. O laço se fez. Costurado, amarrado, entranhado. Tăo meu quanto eu. Tão perto, que nem vejo, ou năo via. 
Ao longo dos anos venho questionando sobre a relaçăo teoria e prática na arte. Sobre esta necessidade de separar, de categorizar. Com as afirmaçóes que ambas estão juntas e năo hierarquizadas, mas que muitas vezes não estâo para além do discurso. A própria relação teoria e prática imbricadas parece se dar na teoria e nâo na prática. $O$ que acontece? Parecemos perdidos no mar da incoerencia.

No meu trabalho de conclusâo de curso em 2008 eu e minha turma fomos provocados a pensar nesta relaçăo. Como criar um trabalho que fosse teórico e prático sem que a teoria tornasse descriçăo da prática ou que a prática fosse uma exemplificaçăo da teoria. Como eles poderiam estar de fato imbricados? Refleti e discuti com meus colegas sobre esta questăo. Na época - com meus 21 anos, com entendimentos e vivências possiveis para esta idade - propus como estratégia elaborar uma questāo-problema única. Que pudesse ser respondida textualmente na escrita de meu trabalho monográfico e no processo de criação artistica. Assim tentei buscar formas de dialogo entre as duas linguagens como parceiras e caminhantes juntas, em relaçâo. Sem predominâncias ou subordinaçōes. Na tentativa de construir os trabalhos em concomitancia.

Assim adotei como questão de estudo: como o corpo se adapta ao ambiente por meío do movimento e de seus canais de percepçăo e, assim, cria dança? Cheguei na questáo da adaptabilidade do corpo em movimento, dos estados corporais, das transformaçбes observadas após as vivências. E com estas transformaçø̋es, com este estado corporal caracteristico e com movimentos emergentes da relaçâo propus uma obra artistica chamada " $A(d a) p t o$ "

No seu processo de criaçăo, que durou um ano entre idas e vindas à montanha fui interrogada inúmeras vezes, por amigos, montanhistas, caminhantes que passaram por mim enquanto pesquisava e criava. Sobretudo gente que tinha como formaçăo acadêmica biologia, engenharia florestal, geografia, geologia. As perguntas mais recorrentes giravam sobre os seguintes aspectos: qual(is) autores eu estava usando para falar de adaptaçåo? Se o que eu afirmava como hipótese experimental já năo tinha sido respondida por Darwin ou outro? De que adaptaçăo eu falava se adaptaçâo era genética e geracional num tempo-escala da evoluçăo?

Insisti ou talvez até teimei que năo iria ler ou nem queria saber as respostas. Para mim - naquele momento - me interessava a experimentaçåo e o que eu poderia observar e criar a partir dela. Nåo quis ler, nem ouvir. Tinha certo para mim que se eu soubesse como ou o que iria acontecer num processo de adaptaçăo, eu, enquanto propositora e criadora do trabalho iria influenciar e até conduzir o trabalho para aquela resposta e, como se diz nas ciências duras, manipular os dados e resultados. Não quis, năo queria e até hoje penso que nâo quero. Me interessava pela escute corporal. Por poder ver e sentir o que emergia da relaçăo com o ambiente. Como cada um dos corpos reagia, agia, se adaptava, como surgiam estados corporais e tornava-mos mais prontos para nos ajustarmos, nos autoorganizarmos, para criarmos.

De inicio pensava em estratégias de improvisaçăo em que o ambiente era gatilho para a improvisaçâo. Ingênua pensava em seu modo mais nu, mais puro. Como se isso existisse ou fosse viável. Tentava levar os corpos para lugares desconhecidos e testar o sempre novo, o acaso, o que chamei de "improvisaçấo forçada" pela relaçăo. Por medo, pelo risco inerente que uma montanha apresenta de danos a vida o corpo se ajustava lançando måo de respostas corporais extremas. Quando funcionava, euforia, superaçăo, quando năo o corpo imóvel, travado, em risco.

\footnotetext{
"O "ator da interioridede" orgulha-se de ter dado à cena o britho da improvisaça. Ele pensa, o ingênuo, que suas improvisap̧es tem algo em comum com a antiga comédia italiana. O "ator da interioridade" nâo sabe que os interpretes da Commedia dellArte $s 0$ desenvolviam suas improvisaçes a partir do roteiro gerado por sua técnica refinada, e nåo de outra maneira. O "ator da interioridede" recusa categoricamente toda técnica - 'a técnica entrava a liberdade de criacjo". É o que ele sempre diz - o "ator da interioridade". Para ele so tem valor o momento de criaçào inconsciente fundamentado na emoglo. Se chega este momento - 60 sucesso; se nåo - o fracasso," (Meierhold in Maria Thais, 2009, D. 333)
}

Aos poucos dou-mo conta que algo permanecia. E isso que permanecia era sobressalente nos corpos, era o que se dava a ver. Era a relaçăo corpo-ambiente all visivel. Era o movimentar-se com fluidez em situaçoes de risco. Era o auto-organizar uma queda. Eram as respostas coletivas. O equilibrio dinâmico. Era emergente e relacional, E estava ali, e eram os movimentos desta dança. 


\section{Neceita ierogui}

\author{
Ingredientes massa: \\ Para cada Ovo: \\ $200 \mathrm{~g}$ de farinha de trigo \\ Um pouco de água morna
}

Sal

\section{Modo de preparo:}

Mistura tudo e deixa descansar por meia hora. Estica a massa e corta com um copo grande. O ponto da massa deve ficar nem mole nern duro.

Ingredientes recheio (quantidade para uma massa com dois ovos):

$200 \mathrm{~g}$ de batatas cozidas e amassadas

$200 \mathrm{~g}$ de ricota fresca

1 ovo

1 pitada de sal

Modo de preparo:

Mistura tudo em uma tigela

Recheia a massa na paima da mâo e aperta as bordas com os dedos enfarinhados

Coloca em cima de um pano húmido para náo grudar, bem separados

Cozinha em água fervendo, quando subir retirar com uma escumadeira

Coloca em uma travessa para servir e vai colocando nata ou creme de leite fresco, a gosto, como molho.

\section{X}

ração

Anre le borge

Coronete thomi

Tesauche premenhe esti

Ranou vetcher dei no tche

But me nilser dado pomer

Esterger duchi

Quila molê

Rove der

Dugicá

Vitno

Amim

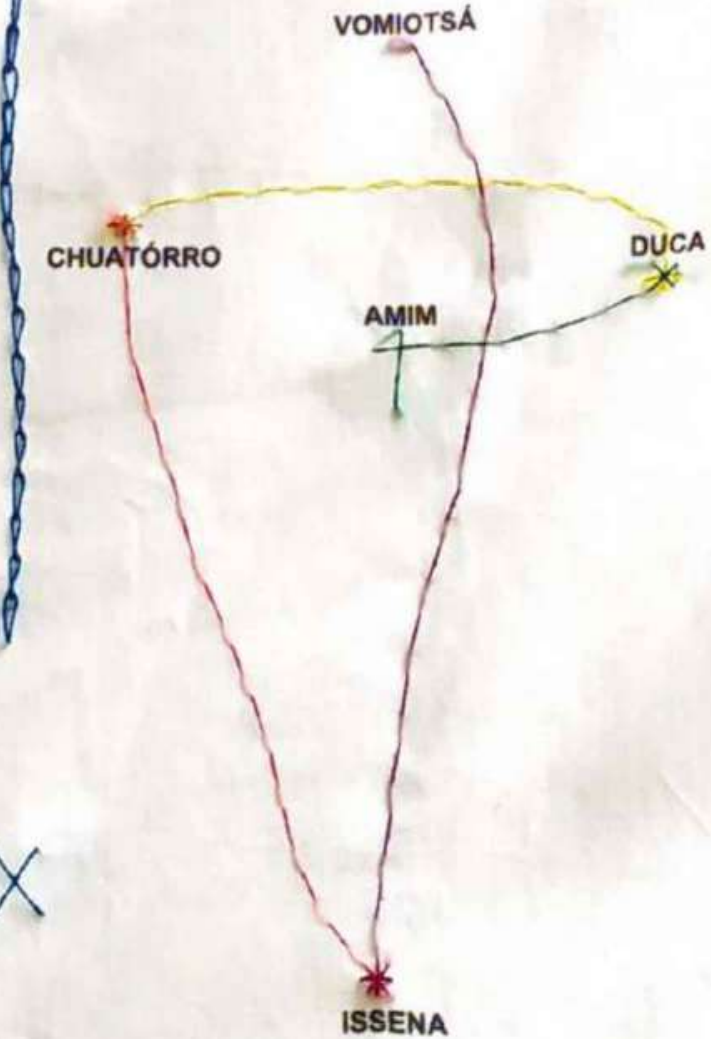


Antes do inicio da disciplina "Da pedagogia à cena (C. Stanislavski - J. Grotowski), da cena à pedagogia (V. Meierhold - T. Kantor ): perspectivas, heranças e friç̧бes" năo sabia multo o que esperar. Apenas insegurança por desconhecer o teatro russo e seus nomes. Logo no começo me cativou a aproximaçăo com o teatro russo a partir do contexto, do ambiente. Do entendimento do que é ser russo, ou melhor ser eslavo.

Despertando em mim um interesse e uma curiosidade quase infantil sobre este lugar tăo distante e tăo desconhecido. A priori me soou como uma escolha feliz e encantadora da nossa professora Maria Thais. Um esforço de uma brasileira em entender o que caracteriza o "ser eslavo" e de nos trazer enquanto mergulho para aproximarmos nossos corpos de tal contexto aonde floresceu o teatro russo.

Aqui, nem de longe imaginava o que estava por vir. Ali eu era apenas uma aluna encantada e cativada pela pedagogia de sua professora. Mas eis que no mergulho - com todos os sentidos curiosos e aguçados - sentimentos me inundam. Uma estranheza por nâo estranhar. O contexto tâo longinquo de uma Rússia desconhecida e distante e que me soa tåo familiar. Questర̋es me rodeiam do porquê conheço, entendo ou me identifico com este lugar?

Por que tudo que minha expectativa "racional" antevira fol por terra e o entendimento e pertencimento do ser eslavo me soa tåo próximo e conhecido?

Me confundo, me emociono, nâo compreendo, sinto o chao cair e descer como a lágrima que percorreu meu rosto naquela aula. Meus sentidos abertos e despreparados nå sabem lidar com aquele conhecimento de vivencia que me invade. Nåo esperava por issol Minha mente inquieta tenta recobrar sua razăo, seu eixo e esquadrinha os quatro cantos de perguntas e respostas. Por que? De onde? $\mathrm{O}$ que e isso?

E de repente como elos que se atam encontro a resposta: Ucraniana, eu, minha avo.

Será?

Me envergonho de perguntar, confesso que năo lembro desta parte da história como eu gostaria ou deveria. Me pergunto novamente: Será?

Estou ali tomada de emoç̋̉es, de reconhecimento e de dúvidas. Meus ouvidos tentam acompanhar e ser "razâo", mas não é mais. Meu corpo pulsa e aquelas informaçðes penetram pelos meus poros. Corno era mesmo "nâo separam teoria da prática?l". E permeada por isso assumo que preciso entender e perguntar.

Pergunto e confirmo. Meu coraçấo ao mesmo tempo pula e se acaima.

Passei a entender parte de mim e a noçăo de ancestralidade parece fazer mais sentido agora. Tâo all, tăo no corpo, tăo de repente e inesperado, tăo indissolúvel e inseparável.

Eu, Thábata, e minha ancestralidade esiava. Parte do meu jeito de interrogar e de lidar com o mundo.

Meu eu tâo diferente que briga e luta para se adequar ou mesmo se aceitar há tempo agora acha pistas de seu lugar de pertencimento. Como năo percebi? Porque isso nåo foi-me ensinado pela razåo, já o meu entendimento de reconhecer foil. E era incompativel. Agora năo mais. 


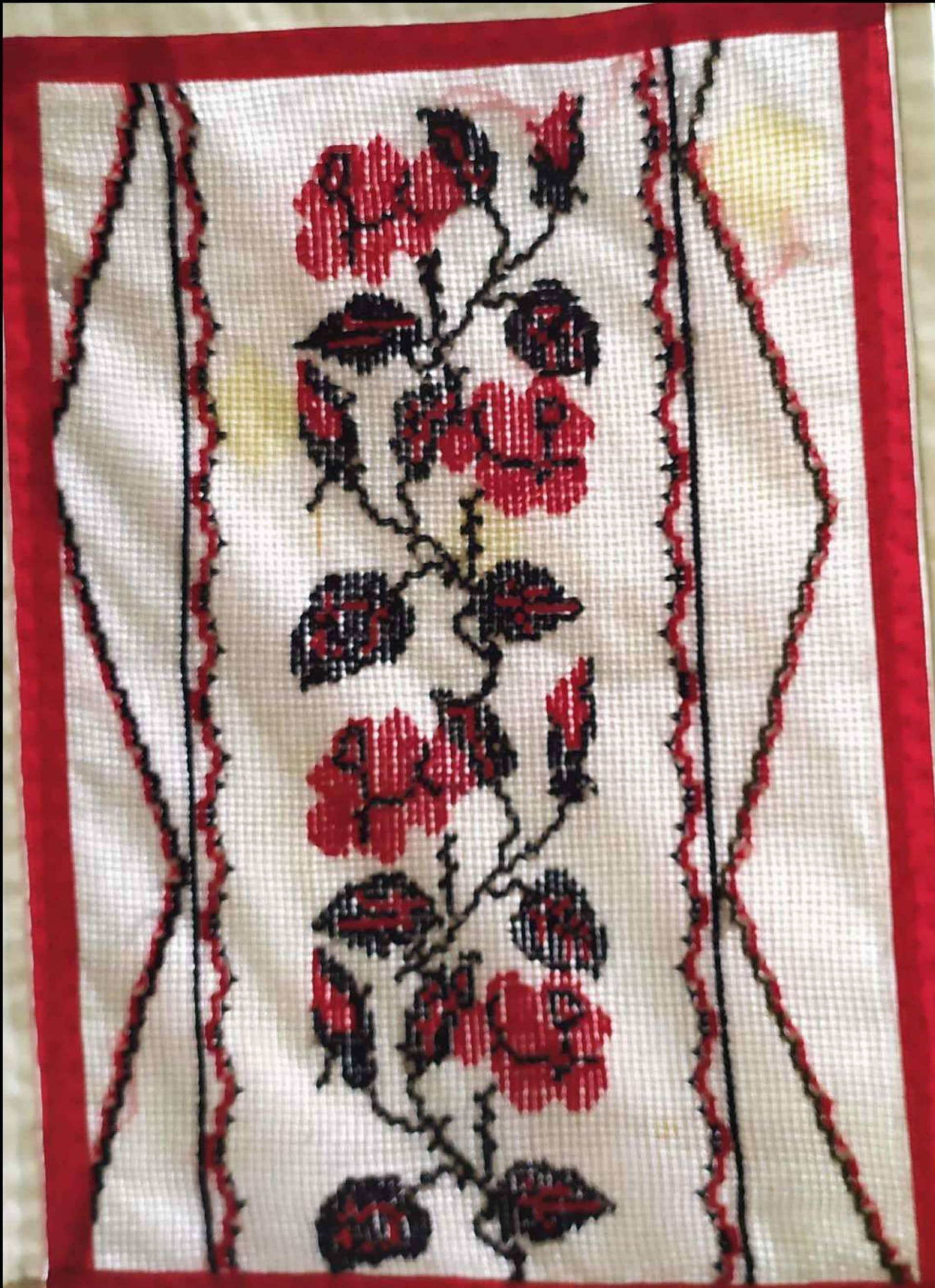

DAPesquisa, Florianópolis, v.15, out. 2020. Escrita Performativa, p. 11-15. 


\section{$V_{\text {tid }}$ \\ Natureza e Arte: sistemas pedagógicos e a agrofloresta}

Como muito do que aprendi na vida veio de minha vó Eliza, plantar e costurar foram destes ensinamentos. Um ensinamento que vern da pratica, do fazer. Cresci vendo mis concertar, pregar botáo, fazer remendo. fazia, fazia e cuidando dos netos nos colocava máquina de costura e disse:

do dia que, já adolescente, ela me sentou na mín

- Vá, vocé já sabel Já me viu fazer mil vezes. Valle cantarolava ou assobiava:

Na lida da terra, revirava, puxava mato, semian pelo plantar, por observar a natureza.

Assim ful aprendendo a criar gosto pela terre, pelo plent

Também pelos trabalhos manuais de costuras ecidimos - eu, meu esposo e minhas filhas - iniciarmos uma horta. Começamos, reviramos Recentemente - após muitas tentativas - conversamos sobre o que plantar, como fazer, comecei a ler sobre solo, sol, hortaliças. de um lado, limpamos aramos de outro. Con dois amigos surgem com a proposta de uma agrofloresta. De repente nossa pequena horta Resolvemos pedir ajuda e nas nossas bus projeto de tornarmos quase autossustentáveis.

me perpassam. Meu corpo rememora o quanto já tinha feito aquele semear, revirar. Em meio a muito arado de terra, memorias de $n$ asso a perceber $e$ a ressignificar quanta coisa que estava ali imbricada naquele fazer.

- penso em seu funcionamento sistêmico. Agora refito sobre a minha pequena agrofloresta, Lembro-me da aula, do exemplo, do entendimeno. Sobre o meu fazer. O quanto entendo agora que tudo está interligado e que estes reduzido no segundo. E penso sobre a pedago dia-a-dia se fazem importantes para o meu fazer profissional. Năo dá para separar As noçōes que se organizam em meu fazer e que văo para a sala de aula. (a) Estou mais criativa, disposta. Construo, crio, teço minha alo car nome. Busco coerência, tropeço, retomo. Voltei a criar. Ainda tateio em busca de aprofundamentos e entendimentos das questốes que me cercam, ainda mu sei também o quẫo jornada. Mas como um broto que saiu da terra e encontra a luz, sei- hoje- que posso crén corporal e fisico será este trabalho, assim como dificil e - porque năo - meêa, na vida, na arte, ne netureza.

processo, é meu fazer pedagógico se construindo,

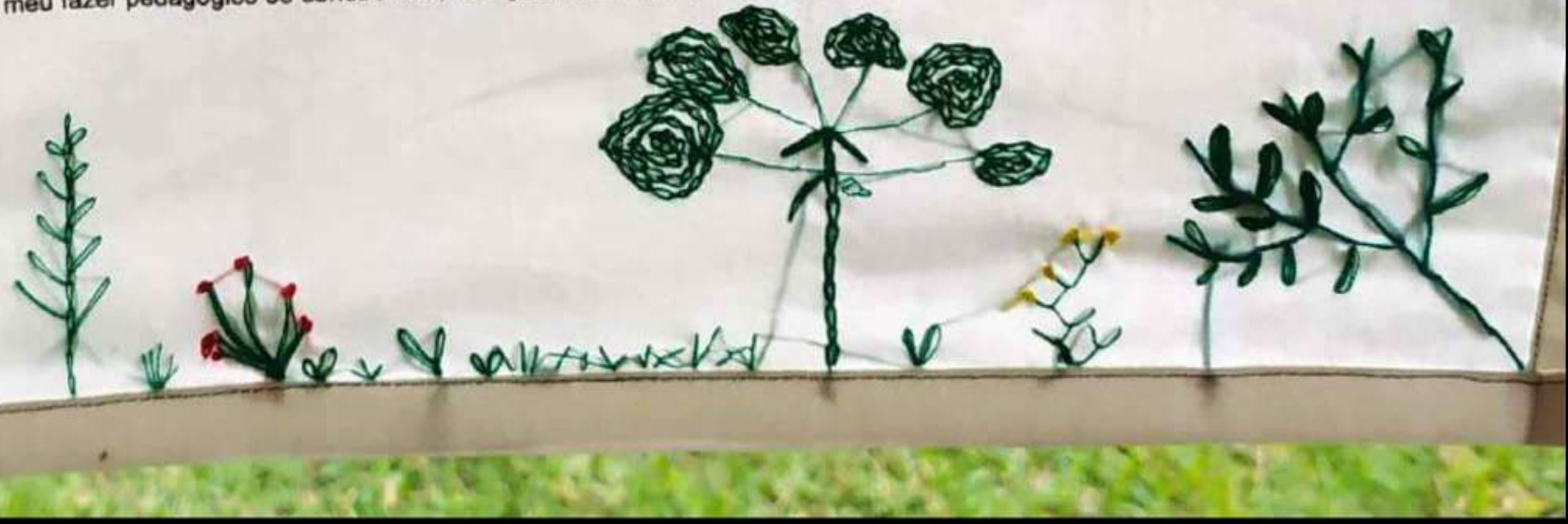



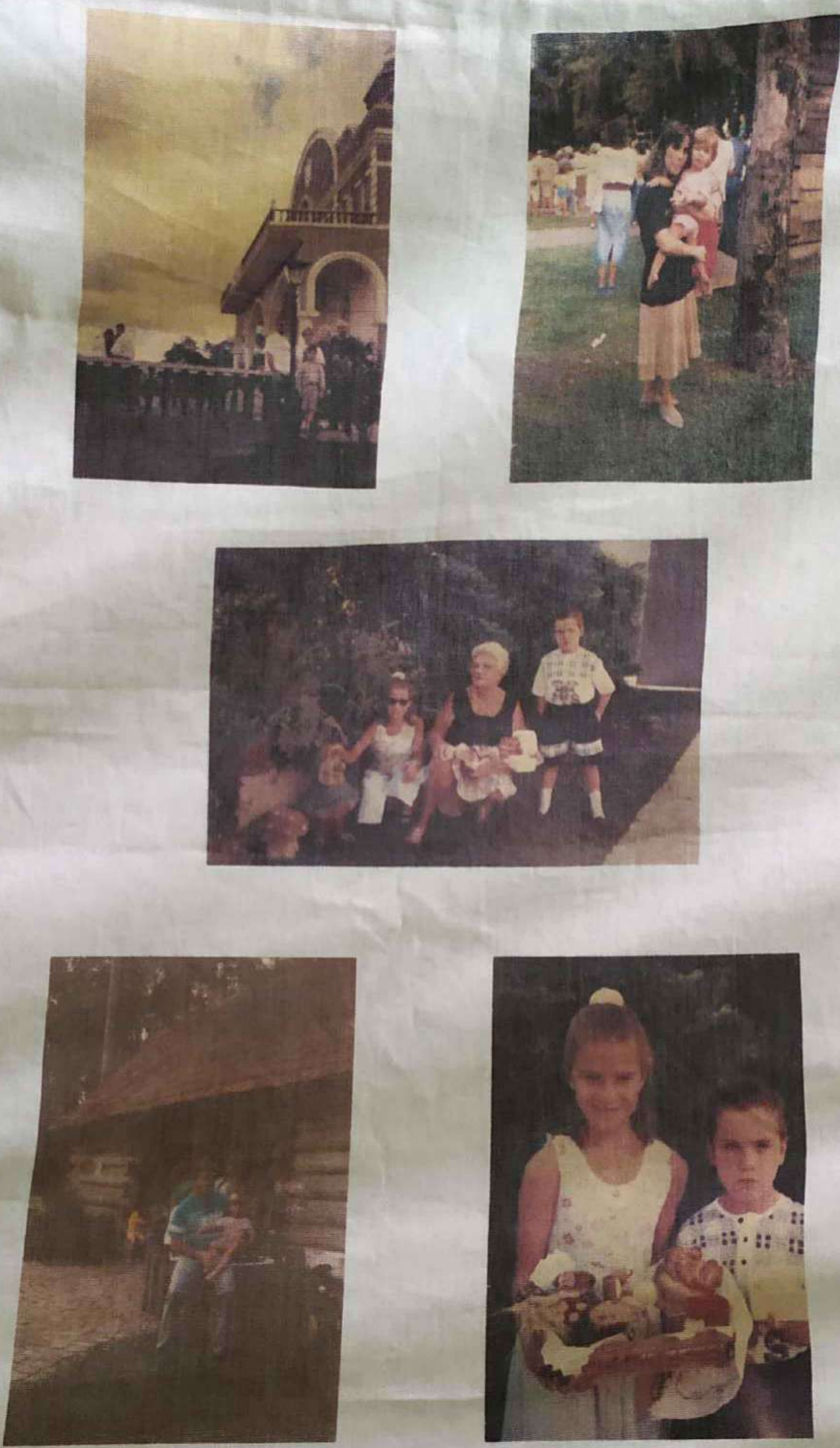

DAPesquisa, Florianópolis, v.15, out. 2020. Escrita Performativa, p. 13-15. DOI: http://dx.doi.org/10.5965/1808312915252020e0030 


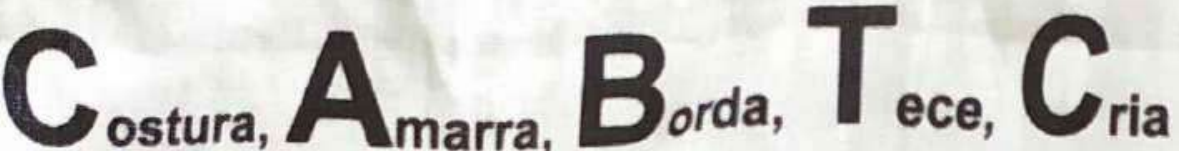

Este ensaio talvez seja um mapa das minhas organizaçбes - ou confusōes - mentais. Ou talvez almeje ser a tal colcha de retalhos a qual tento clarear minhas amarras e costuras. Que precisou assumir este tom de depoimento para apontar o quanto este encontro com este corpo de conhecimentos me desestabilizou e mexeu comigo. Me fazendo questionar e me auto-organizar enquanto percurso de pesquisa. Entendo-o aqui como um auto exercicio de pensamento com o intuito de organizar minhas idelas, o que me move e me inquieta. Adentrando em um novo percurso que me parece mais coerente com o que sou.

Um depoimento de quem sou e de onde venho. De como faço relaç̋es. Uma revisåo sobre corpo e ambiente. Para ao reconhecer minhas questōes e minha ancestralidade possa delinear meu fazer artistico.

Questiono-me, olhando para todos estes aspectos da minha vida que precisei reconhecer e costurar para enfim, chegar aqui. Num ponto em que me pergunto sobre o meu fazer artistico, meu projeto e minha pesquisa. Como numa criaçáo artistica tento dar a ver, tornar visivel - que sinto e meu processo. Meierhold ressoa em minha mente sobre questóes de verdade e da arte.

Me flagro no tentador desejo de trazer a verdade para a cena, $\theta$ me vejo fazendo arte sobre a vida :

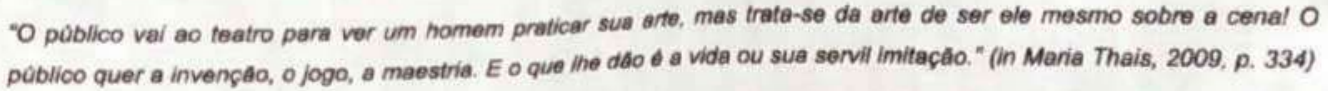

Venho me auto criticando e refletindo há algum tempo sobre como trazer a montanha para a cena e que verdade é esta. Pergunto-me: Como a montanha vem para a cena? Ou refaço a pergunta: $O$ que da montanha vem para a cena? Talvez a montanha năo precise vir para a cena, talvez nâo se tenha meios dela vir.

Penso que a vivência na montanha pode ser um procedimento, uma preparaçăo corporal. Um fazer artistico pedagógico para sensibilizar os corpos para a criaçăo. Pensar a inerente auto-organizaçăo como resposta ao risco e como disparo criativo. Talvez o que venha para a cena é o estado corporal. Mas será? Provocar este estado nåo seria mentira?

Lembro da famosa frase - entre os montanhistas - de Reinhold Messner:

\footnotetext{
- Os dias que estes homens passam nas montanhas säo os dias em que realmente vivem. Quando as cabeças se limpam de teias de aranhe e o sangue corre com força peias veias. Quando os cinco sentidos cobram vitalidade $\theta$ o homem completo se toma mais sensivel e entåo ja pode ouvir as vozes de natureza e ver as belezas que só estavam ao aicance dos mais ousados.
}

Será que o estado do corpo na montanha năo poderia ser pensada como rito? Como tantos ritos de passagem do homem na natureza? Um reencontro, uma superaçăo de limites, um estado alterado de consciência levado pela euforia da superaçăo do medo, pela conquista. Seria um processo ritual? Seria isso que me interessa? Trago um montanhista brasileiro que discute a Ética no Montanhismo para pensar:

"Como é relativamente fácil de constatar, a subide de uma montanha sempre muda a perspectiva do

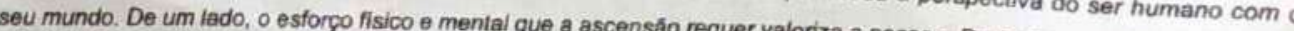
mostra um mundo major e um ser humano (e suas intervençסes na paisagem) mais reduzido. " (Struminski, 2003, p.122)

Seria este estado de corpo, esta possibilidade de ser grande e pequeno frente à natureza. Esta potência que vem da experiência. Mas e como isso compōe um processo criativo? Volto para Meierhold (in Maria Thais, 2009, p. 332) e suas marionetes:

'A marionete nå queria identificar-se completamente ao homem, porque o mundo que ela representa é o maravilhoso de harmonia aonde encontram as cordas de sue arte näo de acordo com as leis da natureza, mas de acordo sobre seus estrados. E aqui me parece que começo a puxar fios deste emaranhado, me sinto ins

de rota. Repenso e nâo vejo mais sentido nos autores que usava. Abend ina por estes novos caminhos, fazendo uma curva Escrevo aqui inebriada, tensa e inquieta na busca por uma

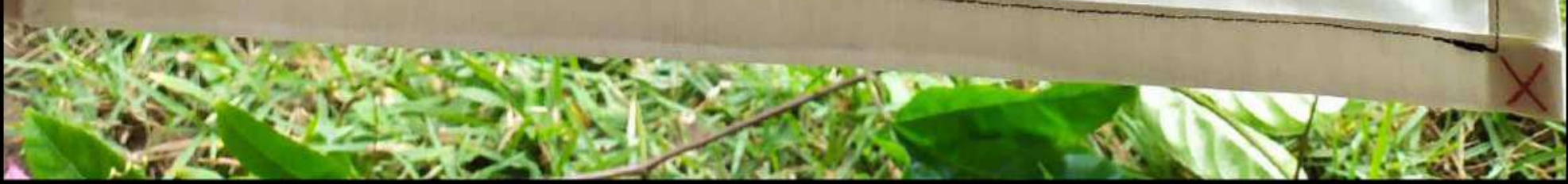

DAPesquisa, Florianópolis, v.15, out. 2020. Escrita Performativa, p. 14-15. DOI: http://dx.doi.org/10.5965/1808312915252020e0030 


\section{REFERÊNCIAS}

MACHADO, A. M. Bisa Bia, Bisa Bel. Rio de Janeiro: Editora Salamandra, 2007.

MEIERHOLD, V. O Teatro de Feira. In: THAís, Maria. Na Cena do Dr. Dapertutto: poética e pedagogia em V.E.Meierhold:1911 a 1916. São Paulo: Perspectiva: Fapesp, 2009.

OLIVEIRA, E. Filosofia da Ancestralidade: corpo e mito na filosofia da educação brasileira. Curitiba: Gráfica e Editora Popular, 2007.

SANTOS, I. F.. Corpo e Ancestralidade: uma proposta pluricultural de dança-arteeducação. São Paulo: Terceira Margem, 2006.

SODRÉ, M. Pensar nagô. Rio de Janeiro: Vozes, 2017.

STRUMINSKI, E. A ética no montanhismo. Desenvolvimento e Meio Ambiente, Curitba, n. 7, p. 121-130, 2003. Disponível em:

https://revistas.ufpr.br/made/article/view/3048/2439 Acesso em 04 ago. 2020.

THAíS, M. Na cena do Dr. Dapertutto: poética e pedagogia em V. E. Meierhold, 1911 a 1916. São Paulo: Perspectiva, 2009. 